\title{
The effectiveness of resilience training on life satisfaction among mothers with mentally retarded children
}

\author{
Sahar Mirghobad Khodarahmi ${ }^{a^{*}}$, Najmeh Sedrpoushan ${ }^{b}$ and Fatemeh Rezaei $^{\mathrm{b}}$
}

${ }^{a}$ M. A. in counseling, Khomeinishahr Branch, Islamic Azad University, Khomeinishahr, Iran ${ }^{b}$ Assistant professor of Islamic Azad University Khomeinishahr Branch, Khomeinishahr, Iran CHRON I C L E A B S T R A T

Article history:

Received June 22, 2013

Received in revised format 28 August 2013

Accepted 21 September 2013

Available online

September 262013

Keywords:

Resilience

Life satisfaction

Mental retardation

\begin{abstract}
The present study investigates the effectiveness of resilience training on life satisfaction among the mothers with mentally retarded children. The method is semi experimental using pretest posttest with control group. Statistical population of research includes elementary mentally retarded student who were enrolled in Najafabad Sareban exceptional school over the period 2012-2013 educational year. Sample group includes 50 subjects who randomly replaced in control and experimental groups. Experimental group members participated in a 10-session resilience training. Finally, both groups completed post-tests where research scales were Diener life satisfaction questionnaire. The data are analyzed by co-variance analysis test. Results are significant and indicates that resilience training is effective on life satisfaction $(\mathrm{p}<0.05)$.
\end{abstract}

(C) 2013 Growing Science Ltd. All rights reserved.

\section{Introduction}

Life satisfaction is one of the primary concerns among human being and there are many studies to measure life satisfaction. Diener et al. (1985), for instance, presented the development and validation of a scale to measure global life satisfaction, the Satisfaction With Life Scale (SWLS). Among the different components of subjective well-being, the SWLS was narrowly concentrated on evaluating global life satisfaction and did not tap related constructs such as positive effects or loneliness. The SWLS was demonstrated to have favorable psychometric properties, including high internal consistency and high temporal reliability. In their study, scores on the SWLS correlated with highly with other measures of subjective well-being, and correlated predictably with specific personality characteristics. The study noted that the SWLS was appropriate for implementation with various age groups, and other potential applications of the scale were investigated.

*Corresponding author. Tel: +989373157212 
Seltzer and Krauss (1989) investigated different predictors of 4 indices of well-being among 203 aging mothers of mentally retarded adults (aged 19-51 yrs) who stayed at home. $49.3 \%$ of Ss were mildly retarded, $35 \%$ were moderately retarded, and the rest either severely $(10.8 \%)$ or profoundly $(4.9 \%)$ retarded. Maternal demographic variables including age, marital status, education, and income were correlated with maternal physical health and life satisfaction, whereas adult child risk factors such as level of retardation and functional skills were associated more strongly with parenting stress and burden. Multiple regression analyses also disclosed that the family's social climate was a better predictor of maternal well-being than was formal or informal support, controlling for maternal and adult child risk factors.

According to Landesman (1986) proposed that the American Association on Mental Deficiency (AAMD) must play a leadership role in defining quality of life and personal life satisfaction for mentally retarded individuals and AAMD has to develop guidelines to help validly measure the degree to which programs, treatments, and environments facilitate achieving positive and rewarding lifestyles.

Cummins (1996) tried to group 173 various domains names derived from the literature under seven headings as implemented by the Comprehensive Quality of Life Scale (ComQol). The study reported that $68 \%$ could be classified in this way. They also reported that life satisfaction, and therefore subjective well-being, could be economically and validly measured through the seven ComQol domains. According to Felce and Perry (1995), quality of life is multidimensional and coverage could be categorised within five dimensions including physical wellbeing, material wellbeing, social wellbeing, emotional wellbeing, and development and activity.

Duvdevany et al. (2002) examined self-determination and lifestyle satisfaction of 80 adults with mild or medium mental retardation living in group homes or their parents' homes. They were evaluated in terms of self-determination, as stated by choices made in the domestic, financial, health, social, and work domains. They also evaluated lifestyle satisfaction with residence, the community, associated services, and employment. They reported that those from group homes were lower on selfdetermination but higher on lifestyle satisfaction, providing support for the commitment to normalization and community inclusion to enhance lifestyle satisfaction. They recommended that service providers and caregivers should encourage and create such opportunities.

Lotan and Ells (2010) investigated adults with intellectual and developmental disabilities and participation in decision making by considering ethical considerations for professional-client practice. Emerson et al. (2008) investigated self-reported well-being of women and men with intellectual disabilities in England. McCallion and McCarron (2007) investigated perspective on quality of life in dementia care. Hagner et al. (2006) studied meaning of homeownership for individuals with developmental disabilities.

\section{The proposed study}

The present study investigates the effectiveness of resilience training on life satisfaction among the mothers with mentally retarded children. The method is semi experimental using pretest posttest with control group. Statistical population of research includes elementary mentally retarded student who were enrolled in Najafabad Sareban exceptional school over the period 2012-2013 educational year. Sample group includes 50 subjects who randomly replaced in control and experimental groups. Experimental group members participated in a 10-session resilience training. Finally, both groups completed post-tests where research scales were Diener life satisfaction questionnaire (Diener et al., 1985). Table 1 summarizes the results of some basic statistics. 
Table 1

The summary of basic statistics

\begin{tabular}{ccccc}
\hline & \multicolumn{3}{c}{ Pre test } & \multicolumn{2}{c}{ Post test } \\
\cline { 2 - 5 } & Mean & Standard deviation & Mean & Standard deviation \\
\hline Experiment & 13.2 & 5.78 & 23.96 & 4.03 \\
Control & 14 & 5.53 & 13.64 & 5.42 \\
\hline
\end{tabular}

As we can observe from the results of Table 1, the mean of experiment groups is increased after the test has been accomplished.

\section{The results}

The proposed study of this paper uses ANOVA test to examine the difference between pre-test and post-test. Table 2 summarizes the results of our investigation.

Table 2

The summary of ANOVA test

\begin{tabular}{cccccccc}
\hline & $\begin{array}{c}\text { Sum of } \\
\text { Squares }\end{array}$ & df & $\begin{array}{c}\text { Mean of } \\
\text { squares }\end{array}$ & F & Sig. & eta & $\begin{array}{c}\text { Power of } \\
\text { test }\end{array}$ \\
\hline Pre-test & 599.63 & 1 & 599.63 & 55.85 & 0.000 & 0.54 & 1 \\
Group & 1452.07 & 1 & 1452.07 & 135.25 & 0.000 & 0.74 & 1 \\
\hline
\end{tabular}

As we can observe from the results of Table 2, there are some differences between two groups, which mean that resilience training were effective on life satisfaction.

\section{Conclusion}

In this paper, we have presented an effectiveness of one of popular life satisfaction tests developed by Diener et al. (1985) among some mothers having mentally restarted children. There is no doubt that many families having mentally children suffer from different problems such as depression or feeling guilty. Some people even consider having mentally retarded child as a kind of punishment. Therefore, it is necessary to prepare some training programs for these people to reduce the negative consequences of having mentally retarded children. This would help society feel better in terms of life satisfaction.

\section{Acknowledgement}

The authors would like to thank the anonymous referees for constructive comments on earlier version of this paper.

\section{References}

Cummins, R. A. (1996). The domains of life satisfaction: An attempt to order chaos. Social Indicators Research, 38(3), 303-328.

Diener, E. D., Emmons, R. A., Larsen, R. J., \& Griffin, S. (1985). The satisfaction with life scale. Journal of personality assessment, 49(1), 71-75.

Duvdevany, I., Ben-Zur, H., \& Ambar, A. (2002). Self-determination and mental retardation: Is there an association with living arrangement and lifestyle satisfaction?. Journal Information, 40(5), 379389. 
Emerson, E., Hatton, C. \& MacLean, Jr., W.E. (2008) Self-reported well-being of women and men with intellectual disabilities in England. American Journal on Mental Retardation, 113(2), 143155.

Felce, D., \& Perry, J. (1995). Quality of life: Its definition and measurement. Research in developmental disabilities, 16(1), 51-74.

Hagner, D., Snow, J., Klein, J., \& Taylor, S.J. (2006). Meaning of homeownership for individuals with developmental disabilities: A qualitative study. Mental Retardation, 44(4), 295-303.

Landesman, S. (1986). Quality of life and personal life satisfaction: Definition and measurement issues. Mental retardation, 24(3), 141-143.

Lotan, G., \& Ells, C. (2010). Adults with intellectual and developmental disabilities and participation in decision making: Ethical considerations for professional-client practice. Journal Information, 48(2), 112-125.

McCallion, P., \& McCarron, M. (2007). Perspective on quality of life in dementia care. Intellectual and Developmental Disabilities, 45(1), 56-59.

Seltzer, M. M., \& Krauss, M. W. (1989). Aging parents with adult mentally retarded children: Family risk factors and sources of support. American Journal on Mental Retardation, 94(3), 303-312. 